\title{
New publications in international humanitarian law and on the International Committee of the Red Cross
}

\section{Arms}

\section{Books}

U. C. Jha, Killer Robots: Lethal Autonomous Weapon Systems Legal, Ethical and Moral Challenges, Vij Books India, New Delhi, 2016, xi + 247 pp.

John Kierulf, Disarmament under International Law, McGillQueen's University Press, Montreal, 2017, xiii + 276 pp.

Samuel Paunila and N. R. Jenzen-Jones (eds), Explosive Weapon Effects: Final Report, Geneva International Centre for Humanitarian Demining, Geneva, 2017, 146 pp.

\section{ICRC Library}

The Library of the International Committee of the Red Cross (ICRC) welcomes researchers interested in international humanitarian law (IHL) and the organization's work throughout the years. Its online catalogue is the gateway to the most recent scholarship on the subject, documents of Diplomatic and International Conferences, all ICRC publications, rare documents published between the founding of the ICRC and the end of the First World War, and a unique collection of military manuals. The Library Team also publishes research guides in order to help researchers access the full text of the most relevant and reliable sources in the field of IHL and the ICRC.*

* The online catalogue is available at: https://library.icrc.org. For the most recent acquisitions, see: library. icrc.org/library/direct.aspx?view=auth\&searchfield=sl\&searchterm $=\% 25 \&$ creationdatestart=t- $90 \&$ from year=t-5. For more information on the research guides, see: blogs.icrc.org/cross-files/category/researchguide. 


\section{Articles}

Maya Brehm, Mark Zeitoun, Harry Konings and Thomas de Saint Maurice, "How to Work towards Reducing the Human Cost of the Use of Explosive Weapons in Populated Areas?", Collegium, No. 46, Autumn 2016, pp. 143-169.

Eric Talbot Jensen, "Emerging Technologies and LOAC Signaling", International Law Studies, Vol. 91, 2015, pp. 621-640.

Hitoshi Nasu, "Nanotechnology and the Future of the Law of Weaponry", International Law Studies, Vol. 91, 2015, pp. 486-516.

Robert Sparrow, "Twenty Seconds to Comply: Autonomous Weapons Systems and the Recognition of Surrender", International Law Studies, Vol. 91, 2015, pp. 699-728.

Sean Watts, "Regulation-Tolerant Weapons, Regulation-Resistant Weapons and the Law of War", International Law Studies, Vol. 91, 2015, pp. 540-621.

Andrew Womack, "The Latest Nuclear War: Does the Use of Depleted Uranium Armaments and Armors Constitute a War Crime?", Vermont Law Review, Vol. 41, No. 2, 2016, pp. 405-428.

\section{Children}

\section{Books}

Francesca Capone, Reparations for Child Victims of Armed Conflict: State of the Field and Current Challenges, Intersentia, Cambridge, 2017, xxxii + 275 pp.

\section{Articles}

Francesca Capone, "Worse' than Child Soldiers? A Critical Analysis of Foreign Children in the Ranks of ISIL", International Criminal Law Review, Vol. 17, No. 1, 2017, pp. 161-185.

Sam Pack, "Targeting Child Soldiers: Striking a Balance between Humanity and Military Necessity", Journal of International Humanitarian Legal Studies, Vol. 7, No. 1, 2016, pp. 183-203.

\section{Conflict, violence and security}

\section{Books}

Kerstin Fisk and Jennifer M. Ramos (eds), Preventive Force: Drones, Targeted Killing, and the Transformation of Contemporary Warfare, New York University Press, New York, 2016, ix + 372 pp. 
Jai Galliott and Mianna Lotz (eds), Super Soldiers: The Ethical, Legal and Social Implications, Ashgate, Farnham and Burlington, VT, 2015, x + 184 pp.

International Institute for Strategic Studies, The IISS Armed Conflict Survey 2016, Routledge, Abingdon and New York, 2016, 340 pp.

\section{Cyber warfare}

\section{Books}

Guillaume Juan, The Challenges of Cyber Warfare to the Laws of Armed Conflict: Humanitarian Impact and Regulation Attempts, University of Glasgow, Glasgow, 2016, 69 pp.

Michael N. Schmitt and Liis Vihul (eds), Tallinn Manual 2.0 on the International Law Applicable to Cyber Operations: Prepared by the International Group of Experts at the Invitation of the NATO Cooperative Cyber Defence Centre of Excellence, 2nd ed., Cambridge University Press, Cambridge, 2017, xli + 598 pp.

\section{Detention}

\section{Articles}

Elisabeth Gilman, "The Case for Strategic U.S. Detention Policy", Military Law Review, Vol. 224, No. 1, 2016, pp. 118-175.

Nathalie Weizmann, "The End of Armed Conflict, the End of Participation in Armed Conflict, and the End of Hostilities: Implications for Detention Operations under the 2001 AUMF", Columbia Human Rights Law Review, Vol. 47, No. 3, 2016, pp. 204-257.

\section{Environment}

\section{Books}

Mara Tignino, Water During and After Armed Conflicts: What Protection in International Law?, Brill, Leiden and Boston, MA, 2016, vi + 111 pp.

\section{Fundamental guarantees}

\section{Books}

Amnesty International, Combating Torture and Other Ill-Treatment: A Manual for Action, 2nd updated and revised ed., London, 2016, 324 pp. 
Dara Kay Cohen, Rape During Civil War, Cornell University Press, London and Ithaca, NY, 2016, xiv + 272 pp.

\section{Articles}

Ashika Singh, "The United States, the Torture Convention, and Lex Specialis: The Quest for a Coherent Approach to the CAT in Armed Conflict", Columbia Human Rights Law Review, Vol. 47, No. 3, 2016, pp. 134-203.

\section{History}

\section{Books}

Michelle Tusan, The British Empire and the Armenian Genocide: Humanitarianism and Imperial Politics from Gladstone to Churchill, I. B. Tauris, London and New York, 2017, xi + 308 pp.

\section{Humanitarian aid}

\section{Books}

Dapo Akande and Emanuela-Chiara Gillard, Oxford Guidance on the Law relating to Humanitarian Relief Operations in Situations of Armed Conflict: Commissioned by the United Nations Office for the Coordination of Humanitarian Affairs, University of Oxford and United Nations Office for the Coordination of Humanitarian Affairs, Oxford and Geneva, 2016, 61 pp.

Philippe Ryfman, Une histoire de l'humanitaire, revised and updated ed., La Découverte, Paris, 2016, 127 pp.

\section{ICRC - International Red Cross and Red Crescent Movement}

\section{Books}

Thomas Brückner, Hilfe schenken: Die Beziehung zwischen dem IKRK und der Schweiz 1919-1939, Neue Zürcher Zeitung, Zürich, 2017, 272 pp.

Cédric Cotter, (S')Aider pour survivre: Action humanitaire et neutralité suisse pendant la Première Guerre Mondiale, University of Geneva, Geneva, 2016, 575 pp.

Alfonso García López, Entre el odio y la venganza: El CICR en la guerra civil española, Espacio Cultura Editores, La Coruña, 2016, 336 pp.

Nicasio Landa, Guillermo Sánchez and Jon Arrizabalaga, Muertos y heridos y otros textos, Pamiela Extea, Navarra, 2016, 334 pp. 
Gerald Steinacher, Humanitarians at War: The Red Cross in the Shadow of the Holocaust, Oxford University Press, Oxford and New York, 2017, xiv + 330 pp.

\section{Articles}

André Durand, "Gustave Moynier: La discorde", Cahiers de Genève Humanitaire, No. 9, 19 December 2015, pp. 37-44.

André Durand, "Gustave Moynier: Révision de la Convention (1868) et Conférence de Berlin (1869). Annexe: Convention de Genève de 1864", Cahiers de Genève Humanitaire, No. 10, January-June 2016, pp. 39-52.

Roger Durand, "Cartes postales illustrées de Gustave Ador", Cahiers de Genève Humanitaire, No. 9, 19 December 2015, pp. 10-36.

Jean-François Fayet, "Le CICR et la Russie: Un peu plus que de l'humanitaire", Connexe: Les Espaces Postcommunistes en Question(s), 2015, pp. 55-74.

Filippo Maria Giordano, “Un portrait de Louis Appia entre l'Italie et l'Europe: Foi évangélique, vision cosmopolite et engagement humanitaire dans les guerres du Risorgimento", Cahiers de Genève Humanitaire, No. 10, January-June 2016, pp. 39-52.

\section{International criminal law}

\section{Books}

William A. Schabas, The International Criminal Court: A Commentary on the Rome Statute, 2nd ed., Oxford University Press, Oxford, 2016, xci + 1589 pp.

\section{Articles}

Rosa Ana Alija Fernández and Jaume Saura Estapà, "Towards a Single and Comprehensive Notion of 'Civilian Population' in Crimes against Humanity", International Criminal Law Review, Vol. 17, No. 1, 2017, pp. 47-77.

Serge Brammertz et al., "Attacks against Cultural Heritage as a Weapon of War: Prosecutions at the ICTY", Journal of International Criminal Justice, Vol. 14, No. 5, 2016, pp. 1143-1174.

Paige Casaly, "Al Mahdi before the ICC: Cultural Property and World Heritage in International Criminal Law", Journal of International Criminal Justice, Vol. 14, No. 5, 2016, pp. 1199-1220.

Marie-Alice D'Aoust, "Sexual and Gender-Based Violence in International Criminal Law: A Feminist Assessment of the Bemba Case", International Criminal Law Review, Vol. 17, No. 1, 2017, pp. 208-221. 
Martyna M. Falkowska, "The Bemba Trial before the International Criminal Court: Defining an Armed Conflict through the Scope of a Commander's Responsibility", Revue de Droit Militaire et de Droit de la Guerre/The Military Law and Law of War Review, Vol. 54, No. 2, 2015-16, pp. 267-296.

Laurel E. Fletcher, "A Wolf in Sheep's Clothing? Transitional Justice and the Effacement of State Accountability for International Crimes", Fordham International Law Journal, Vol. 39, No. 3, 2016, pp. 447-531.

Beatriz Garrigues Garrido, "Violencia sexual y conflictos armados: La respuesta de la comunidad internacional", Revista Española de Derecho Militar, No. 105, JanuaryJune 2016, pp. 153-192.

Windell Nortje, "Victim or Villain: Exploring the Possible Bases of a Defence in the Ongwen Case at the International Criminal Court", International Criminal Law Review, Vol. 17, No. 1, 2017, pp. 186-207.

Dan Saxon, "Violations of International Humanitarian Law by Non-State Actors during Cyberwarfare: Challenges for Investigations and Prosecutions", Journal of Conflict and Security Law, Vol. 21, No. 3, 2016, pp. 555-574.

\section{International human rights law}

\section{Books}

Thomas W. Smith, Human Rights and War through Civilian Eyes, University of Pennsylvania Press, Philadelphia, PA, 2017, x + 256 pp.

\section{Articles}

David S. Goddard, "Applying the European Convention on Human Rights to the Use of Physical Force: Al-Saadoon", International Law Studies, Vol. 91, 2015, pp. 402-424.

\section{International humanitarian law - conduct of hostilities}

\section{Articles}

Randall Bagwell and Molly Kovite, "It Is Not Self-Defense: Direct Participation in Hostilities Authority at the Tactical Level", Military Law Review, Vol. 224, No. 1, 2016, pp. 1-47.

ICRC and Collège d'Europe, "Urban Warfare: Proceedings of the 16th Bruges Colloquium, 15-16 October 2015/La guerre en milieu urbain: Actes du 16e Colloque de Bruges, 15-16 octobre 2015", Collegium, No. 46, Autumn 2016, 189 pp. 
Geoffrey S. Corn and James A. Schoettler, "Targeting and Civilian Risk Mitigation: The Essential Role of Precautionary Measures", Military Law Review, Vol. 223, No. 4, 2015, pp. 785-842.

Nathalie Durhin and Marco Sassòli, "Protecting Civilians Living in Cities against the Effects of Hostilities", Collegium, No. 46, Autumn 2016, pp. 61-88.

E. Patrick Gilman, "Operation Billy Goat: The Targeting and Killing of a United States Citizen on United States Soil", Military Law Review, Vol. 223, No. 4, 2015, pp. 843-896.

Françoise Hampson and Sean Watts, "Can Siege Warfare still be Legal?", Collegium, No. 46, Autumn 2016, pp. 89-107.

Kevin Jon Heller, "Disguising a Military Object as a Civilian Object: Prohibited Perfidy or Permissible Ruse of War?", International Law Studies, Vol. 91, 2015, pp. 517-539.

Ian Henderson, Jordan den Dulk and Angeline Lewis, "Emerging Technology and Perfidy in Armed Conflict", International Law Studies, Vol. 91, 2015, pp. $468-485$.

Agnieszka Jachec-Neale, Nobuo Hayashi and Charles Barnett, "Identifying Military Objectives in Cities", Collegium, No. 46, Autumn 2016, pp. 17-42.

Guy Keinan, Laurent Gisel and Eric Jensen, "The Prohibition on Indiscriminate and Disproportionate Attacks", Collegium, No. 46, Autumn 2016, pp. 109-141.

Vaios Koutroulis and Clive Baldwin, "Precautions When Carrying Out Attacks in Cities", Collegium, No. 46, Autumn 2016, pp. 43-60.

Julia Liebermann, "The Scope of Application of International Humanitarian Law in Non-International Armed Conflicts: Analysing State Practice from Colombia", Humanitäres Völkerrecht: Informationsschriften/Journal of International Law of Peace and Armed Conflict, Vol. 29, No. 4, 2016, pp. 146-158.

John J. Merriam, "Affirmative Target Identification: Operationalizing the Principle of Distinction for U.S. Warfighters", Virginia Journal of International Law, Vol. 56, No. 1, 2016, pp. 83-146.

Tamar Meshel, "A Decade Later and Still on Target: Revisiting the 2006 Israeli Targeted Killing Decision", Journal of International Humanitarian Legal Studies, Vol. 7, No. 1, 2016, pp. 88-128.

Robert Lawton Pratt, "The International Legal Prohibition on Perfidy and its Scope in Non-International Armed Conflicts", Virginia Journal of International Law Digest, Vol. 56, 2016, pp. 1-9. 


\section{International humanitarian law - general}

\section{Books}

Maartje Abbenhuis, Christopher Ernest Barber and Annalise R. Higgins, War, Peace and International Order? The Legacies of the Hague Conferences of 1899 and 1907, Routledge, London and New York, 2017, ix + 229 pp.

Saba Bazargan-Forward and Samuel C. Rickless, The Ethics of War: Essays, Oxford University Press, New York, 2017, xxiii + 278 pp.

Andrew Borene, Alice Beauheim Borene and Michael Sullivan (eds), International Humanitarian Law (Law of Armed Conflicts) Sourcebook, American Bar Association, Chicago, IL, 2014, xii + 756 pp.

ICRC, Commentary on the First Geneva Convention: Convention (I) for the Amelioration of the Condition of the Wounded and Sick in Armed Forces in the Field, 2nd ed., Cambridge University Press and ICRC, Cambridge and Geneva, 2016, xxiv +1344 pp.

Adil Ahmad Haque, Law and Morality at War, Oxford University Press, Oxford, 2017, 285 pp.

Etienne Henry, Le principe de nécessité militaire: Histoire et actualité d'une norme fondamentale $d u$ droit international humanitaire, A. Pedone, Paris, 2016, 827 pp.

U. C. Jha and K. Ratnabali, The Law of Armed Conflict: An Introduction, Vij Books India, New Delhi, 2017, xvi + 602 pp.

Frédéric Joli et al., Vers un nouvel ordre juridique: l'humanitaire? Mélanges en l'honneur de Patricia Buirette, LGDJ, Paris, 2016, 468 pp.

Daniel Lagot, Le droit international et les guerres de notre temps, L'Harmattan, Paris, 2016, 205 pp.

Frauke Lachenmann and Rüdiger Wolfrum (eds), The Law of Armed Conflict and the Use of Force, Oxford University Press, Oxford and New York, 2017, xxxii + 1427 pp.

\section{Articles}

Amanda Alexander, "International Humanitarian Law, Postcolonialism and the 1977 Geneva Protocol I", Melbourne Journal of International Law, Vol. 17, No. 1, 2016, pp. 1-36.

Cedric de Koker and Tom Ruys, "Foregoing Lex Specialis? Exclusivist v. Symbiotic Approaches to the Concurrent Application of International Humanitarian and Human Rights Law", Revue Belge de Droit International/Belgian Review of International Law/Belgisch Tijdschrift voor Internationaal Recht, Vol. 49, No. 2016/1, 2016, pp. 240-287. 
Samuel Longuet, "La définition des maux superflus en droit des conflits armés", Revue de Droit Militaire et de Droit de la Guerre/Military Law and Law of War Review, Vol. 54, No. 2, 2015-16, pp. 245-265.

Heike Spieker, "Protecting the Unprotected: Zum Schutz humanitärer Hilfsaktion im bewaffneten Konflikt", Humanitäres Völkerrecht: Informationsschriften/Journal of International Law of Peace and Armed Conflict, Vol. 29, No. 4, 2016, pp. 129-136.

\section{International humanitarian law - implementation}

\section{Books}

Bryan Frederick and David E. Johnson, The Continued Evolution of U.S. Law of Armed Conflict Implementation: Implications for the U.S. Military, National Defense Research Institute, RAND Corporation, Santa Monica, CA, 2015, xx + 114 pp.

\section{Articles}

Alon Margalit, "Recent Trends in the Application of Human Rights and Humanitarian Law: Are States Losing Patience?", Journal of International Humanitarian Legal Studies, Vol. 7, No. 1, 2016, pp. 156-182.

Chris Rogers, "The Forever War, in the Hands of Others: Tracing the Real Power of U.S. Law and Policy in the War on Terror", Columbia Human Rights Law Review, Vol. 47, No. 3, 2016, pp. 78-133.

\section{International humanitarian law - types of actors}

\section{Books}

Mohamad Ghazi Janaby, The Legal Regime Applicable to Private Military and Security Company Personnel in Armed Conflicts, Springer, Dordrecht, 2016, xv + 237 pp.

Nadarajah Pushparajah, Human Rights Obligations of Armed Non-State Actors in Non-International Armed Conflicts, Wolf Legal Publishers, Oisterwijk, 2016, $\mathrm{xii}+320 \mathrm{pp}$.

Tilman Rodenhäuser, Armed Groups under International Humanitarian Law, Human Rights Law, and International Criminal Law: What Degree of Organisation Is Required?, IHEID, Geneva, 2016, xli + 361 pp.

\section{Articles}

Stella Ageli, "Private Military Companies (PMCs) and International Criminal Law: Are PMCs the New Perpetrators of International Crimes?", Amsterdam Law Forum, Vol. 8, No. 1, 2016, pp. 28-47. 
Helene Hojfeldt, "Prohibiting Participation in Armed Conflict", Revue de Droit Militaire et de Droit de la Guerre/Military Law and Law of War Review, Vol. 54, No. 1, 2015-16, pp. 13-31.

Astrid Kjeldgaard-Pedersen, "A Ghost in the Ivory Tower: Positivism and International Legal Regulation of Armed Opposition Groups", Journal of International Humanitarian Legal Studies, Vol. 7, No. 1, 2016, pp. 32-62.

Camille Marquis Bissonnette, "The Definition of Civilians in Non-International Armed Conflicts: The Perspective of Armed Groups", Journal of International Humanitarian Legal Studies, Vol. 7, No. 1, 2016, pp. 129-155.

\section{International humanitarian law - types of armed conflict}

\section{Books}

Michael John-Hopkins, The Rule of Law in Crisis and Conflict Grey Zones: Regulating the Use of Force in a Global Information Environment, Routledge, London and New York, 2017, xii + 333 pp.

\section{Articles}

Djemila Carron, "Transnational Armed Conflicts: An Argument for a Single Classification of Non-International Armed Conflicts", Journal of International Humanitarian Legal Studies, Vol. 7, No. 1, 2016, pp. 5-31.

Elies Van Sliedregt, "Command Responsibility and Cyberattacks", Journal of Conflict and Security Law, Vol. 21, No. 3, 2016, pp. 505-521.

\section{Law of naval warfare}

\section{Books}

Scott Andrew Keefer, The Law of Nations and Britain's Quest for Naval Security: International Law and Arms Control, 1898-1914, Palgrave Macmillan, Cham, 2016, xi + 326 pp.

\section{Articles}

James Kraska and Michael Monti, "The Law of Naval Warfare and China's Maritime Militia”, International Law Studies, Vol. 91, 2015, pp. 450-467. 


\section{Protected objects}

\section{Books}

Sabine von Schorlemer, Kulturgutzerstörung: Die Auslöschung von Kulturerbe in Krisenländern als Herausforderung für die Vereinten Nationen, Nomos, BadenBaden, 2016, 1025 pp.

Jiri Toman, Les biens culturels en temps de guerre: Quel progrès en faveur de leur protection? Commentaire article-par-article du Deuxième Protocole de 1999 relatif à la Convention de la Haye de 1954 pour la protection des biens culturels en cas de conflit armé, UNESCO, Paris, 2015, 1110 pp.

\section{Articles}

Alexandros Kolliopoulos, "La destruction ciblée des monuments et sites archéologiques en période de conflit armé et la dimension culturelle de la paix international", Annuaire Français de Droit International, Vol. 61, 2015, pp. 119-143.

Mark V. Vlasic and Helga Turku, “'Blood Antiquities': Protecting Cultural Heritage beyond Criminalization", Journal of International Criminal Justice, Vol. 14, No. 5, 2016, pp. 1175-1198.

\section{Public international law}

\section{Books}

Pia Acconci et al., International Law and the Protection of Humanity: Essays in Honor of Flavia Lattanzi, Brill Nijhoff, Leiden and Boston, MA, 2017, xix + 564 pp.

Jens David Ohlin and Larry May, Necessity in International Law, Oxford University Press, Oxford, 2016, xi +280 pp.

Laura Salvadego, Struttura e funzioni della necessità militare nel diritto internazionale, G. Giappichelli, Torino, 2016, xv + 332 pp.

\section{Articles}

Russell Buchan and Nicholas Tsagourias (guest eds), "Non-State Actors and Responsibility in Cyberspace: State Responsibility, Individual Criminal Responsibility and Issues of Evidence", Journal of Conflict and Security Law, Vol. 21, No. 3, 2016, pp. 377-593.

Eliav Lieblich, "Internal Jus ad Bellum”, Hastings Law Journal, Vol. 67, No. 3, 2016, pp. $687-748$. 


\section{Refugees/displaced persons}

\section{Books}

Allehone M. Abebe, The Emerging Law of Forced Displacement in Africa: Development and Implementation of the Kampala Convention on Internal Displacement, Routledge, London and New York, 2017, xii + 307 pp.

Cathryn Costello, The Human Rights of Migrants and Refugees in European Law, Oxford University Press, Oxford, 2016, xli + 356 pp.

Volker Türk, Alice Edwards and Cornelis Wouters, In Flight from Conflict and Violence: UNHCR's Consultations on Refugee Status and other Forms of International Protection, Cambridge University Press, Cambridge, 2017, xvii + 306 pp.

\section{Articles}

Kirsten MacConnachie et al., "Humanitarianism in Refugee Camps", Humanity: An International Journal of Human Rights, Humanitarianism, and Development, Vol. 7, No. 3, 2016, pp. 391-468.

\section{Terrorism}

\section{Books}

Paul Rogers, Irregular War: ISIS and the New Threat from the Margins, I. B. Tauris, London and New York, 2016, xii + 244 pp.

\section{Women/gender}

\section{Books}

Sahla Aroussi, Women, Peace and Security: Repositioning Gender in Peace Agreements, Intersentia, Cambridge, 2015, xiv + 332 pp.

Alexis Leanna Henshaw, Why Women Rebel: Understanding Women's Participation in Armed Rebel Groups, Routledge, London and New York, 2017, xiii + 133 pp.

Tanya Narozhna and W. Andy Knight, Female Suicide Bombings: A Critical Gender Approach, University of Toronto Press, London, 2016, $\mathrm{x}+266 \mathrm{pp}$. 